\title{
How Computers Affect Management
}


Other books by the same author:

MANAGEMENT SUCCESSION

THE REALITY OF MANAGEMENT

THE BOSS: THE LIFE AND TIMES OF THE

BRITISH BUSINESSMAN (with Roy Lewis)

MANAGERS AND THEIR JOBS

THE REALITY OF ORGANIZATIONS: A GUIDE FOR MANAGERS 


\section{HOW COMPUTERS}

\section{AFFECT MANAGEMENT}

Rosemary Stewart

Macmillan Education 
(C) Rosemary Stewart 1971 Softcover reprint of the hardcover 1st edition 1971 All rights reserved. No part of this publication may be reproduced or transmitted, in any form or by any means, without permission.

First published 1971 by THE MACMILLAN PRESS LTD

London and Basingstoke Associated companies in New York Toronto Dublin Melbourne Johannesburg and Madras

ISBN 978-1-349-01109-4 ISBN 978-1-349-01107-o (eBook) DOI 10.1007/978-1-349-01107-o 


\section{Contents}

LIST OF TABLES AND DIAGRAM

vi

ACKNOWLEDGEMENTS

vii

INTRODUCTION

ix

Part I: Aims and Plan of Research

I Aims and Methods of Research 3

2 Classifying Computer Effects II

Part II: The Case Studies

3 Clerical Procedures $\quad 29$

Branch Banking $\quad 29$

Oxford University Press $\quad 39$

West Midlands Gas Board $\quad 46$

4 Production Planning and Control 48

Introduction $\quad 48$

Flowmix (Pseudonym) $\quad$ so

Patulum (Pseudonym) 69

Hidcote (Pseudonym) 9I

Hayward Tyler $\quad$ IO8

Commentary is

5 Investment Planning Models $\quad$ I28

British Petroleum $\quad$ I28

Gas Council $\quad$ I72

British Oxygen $\quad$ I8I

Part III: The Findings

6 Relations between Computer Staff and User Management I7I

7 How Computers Affect Management 209

8 Managerial Understanding 229

9 Implications for Management 235

INDEX 


\section{List of Tables and Diagram}

Table I Potential effects on management from different types of computer applications

2 Patulum: Hierarchy of factors attributed to the two problems of inaccuracy and lack of forward control over production

3 Patulum: Perception of problems by time periods

4 Potential effects on management from different types of computer applications compared with actual effects in case-study companies.

5 Impact on managers' jobs after implementation

6 Assessing the importance of the impact on managers' jobs

Diagram I The ways in which management is affected by the computer 


\section{Acknowledgements}

THIS research was made possible by the generous co-operation of the organizations studied. I am especially grateful to the managements concerned for their forbearance when given the opportunity to criticize and amend the case studies. Almost invariably, they believed that research should be unedited, except for the correction of factual errors, and agreement for publication was given without any change of substance. I am particularly grateful to British Petroleum where the management gave such full co-operation in what proved to be an unusually interesting study. I am also very grateful to British Oxygen, the Gas Council, Hayward Tyler, the Oxford University Press and the West Midlands Gas Boards as well as to the other companies which prefer to remain anonymous.

I owe a considerable debt to the two main research workers, Michael White and Nicholas Woodward, without whom this book could not have been written. They both worked on the last two years of the project, while in the preliminary stages I was assisted by another research worker, Marcia Grant. Michael White collaborated with me on the research at British Petroleum and wrote the draft of this case study. $\mathrm{He}$ also did the field work in Flowmix, the Gas Council and British Oxygen and drafted the corresponding case studies. Nicholas Woodward did most of the field work in the Bank, and all of it in Hidcote, Oxford University Press and West Midlands Gas Board. He also wrote the draft case studies of these. Both men did the field work in Patulum and Michael White drafted the case history. Michael White is also coauthor of an article which forms the basis of Chapter 2. I was exceptionally fortunate in the research workers, whose ideas and work have contributed much to this book.

The main part of the research, which lasted two years and nine months, was financed by the Social Science Research Council. I am most grateful to them and to the Oxford Centre for Management Studies for providing facilities and time for the research and writing.

Oxford Centre for Management Studies,

Rosemary Stewart 30 December 1970 


\section{Introduction}

COMPUTERS will revolutionize management and the organizations within which management works. This prediction has been made by different writers for over ten years. True or not - and it certainly has not come true yet - the computer has both provided a major new tool for management and added a large new innovating group to the organization. What effects has this had on management? In what ways has it changed what managers do? What demands has it made upon them? Has it affected how they think about the problems of their business? Has it altered the structure of the organization? The author, with her assistants, has just completed a three-ycar research project aimed at answering these questions in the companies studied, which were chosen as specimens each with different types of computer applications.

This book is principally addressed to two groups of readers. First, it is addressed to managers who want to learn how to employ the computer, and computer specialists, more effectively, or who want to know how particular types of computer applications may affect them. Secondly, it is addressed to those computer specialists whose interests are wider than the technical aspects of their work. The book should also be of special interest to training officers who want to help managers to cope better with the demands of the computer facility, and to research workers and teachers in management studies.

\section{GUIDE TO READING THIS BOOK}

This is a longer book than the author would have wished, knowing how much there is to read and how little time most people, especially managers, have for doing so. The format is therefore designed to help the reader to decide which parts of the book are likely to be of chief interest to him. Probably Part III is of most general interest since it consists of a commentary upon the findings and lessons of the case studies. Each chapter in it has a summary at the end. The implications of the research for management are summarized in the last chapter. Part I consists of a description of the aims and methods of the research 
and of the forms of classification used in analysing the case studies. Hard-pressed managers are advised at least to read the summaries of the two chapters, which comprise Part I and to look at the diagram on p. 24 which summarizes the different sources of effects of management from the computer. Part II contains the case studies which are grouped into chapters according to the type of computer application. Each case study starts with a summary of the main points of interest so that the reader can quickly tell whether it may be of interest to him. Each case study follows a standard format with background information first, followed by a history of the application studied and finally an interpretation of what happened, including an analysis of the effects on management. 